\title{
Essays
}

\section{The Italian Theory of Comparative Law Goes Abroad}

\author{
Elisabetta Grande \\ School of Law, University of Eastern Piedmont, Alessandria, Italy \\ elisabetta.grande@uniupo.it \\ Rodrigo Míguez Núñez \\ School of Law, University of Eastern Piedmont, Alessandria, Italy \\ rodrigo.miguez@uniupo.it \\ Pier Giuseppe Monateri \\ School of Law, University of Turin, Turin, Italy \\ pier.monateri@unito.it
}

\begin{abstract}
The aim of this paper is to assess the influence of the Italian comparative law scholarship outside its national boundaries, and particularly in Latin America, where it has had its strongest impact. In order to achieve our goal we will start by sketching a picture of the current status of the Italian comparative law, tracing its roots, explaining its development and analyzing its weaknesses and strengths. After exploring its reception in South America, we will ultimately try to envisage the future challenges, directions and contributions of the Italian Theory - as we labeled the Italian comparative law "way".
\end{abstract}

\section{Keywords}

Italy - comparative law - legal formants - Italian comparative way - Latin America 


\section{Comparative Law in Italy: Emergence and Development of a Discipline $^{*}$}

\section{1}

\section{The Emergence of Comparative Law in Twentieth Century Italy}

Claims of an earlier origin for the sake of a more respectable pedigree notwithstanding, ${ }^{1}$ the story of comparative law begins in Italy in the early part of the twentieth century. Since then, three fundamental layers have been at play: a commercial law branch, a reformist tradition, and a mainstream, "scientific" approach. In time, each of them proved to be very significant for the development of the discipline. or not to Cross the Channel

During the Fascist era (1922-43), England was at the top of the list of official (political) contempt, and English law was simply not on the radar of Italian jurists at all. The same was true for the United States and American law. The common law tradition was treated with contempt, and Italian jurists tended to doubt whether Anglo-American "law" really even deserved that name. This attitude resulted in a deep and self-inflicted ignorance virtually about the entire common law tradition.

Yet, there was a major exception. A small group of commercial law scholars, among them masters such as Tullio Ascarelli (1903-1959), Mario Rotondi (1900-1984), and Angelo Sraffa (1865-1937), worked in the less parochial and more cosmopolitan spirit traditionally associated with commercial law and thus began to look across the Channel and even across the Atlantic. They were the first to take an interest in topics later to become classics of comparative law - questions of the nature and sources of law or institutions like the trust. This group, consisting in part of Jewish scholars who were forced to emigrate by racist laws, was instrumental in working towards an "integrative" comparison. Its members rejected the idea that the diversity of positive law created by national codifications (even in the domain of commercial law) essentially precluded effective communication among different legal systems - an idea that left international legal practice without a useful legal regime altogether.

* While this essay is the product of a collaboration among the three Authors, part I is however to be attributed to Elisabetta Grande, part II to Rodrigo Míguez, and part III to Pier Giuseppe Monateri.

$1 \quad$ In 1985 in Palermo, for instance, the Associazione Italiana di Diritto Comparato officially declared the early nineteenth century Sicilian jurist Emerico Amari (1810-1870), author of an encyclopedic survey of foreign legislation (Critica di una scienza delle legislazioni comparate, first published 1857 , Soveria Mannelli, 2005), to be the ancestor of the discipline. 
Their early efforts at comparative studies were motivated by practical and professional concerns but, at the time, they nevertheless constituted the cutting edge of comparative legal scholarship in Italy. Their methodology was remarkably open-minded, and they were fully capable of looking through legal forms to the substance underneath.

Yet, while highly influential in the domain of commercial law, these scholars had little influence in the general domain of Italian jurisprudence. This tradition therefore remained completely uninfluential until after the Second World War.

The Reformists in the Post-World War II Period: Broadening the View

In the aftermath of the Second World War, the United States exerted pressure on Italy, as well as on Germany and Japan, to (re-)establish at least a local version of the rule of law. In this political climate, the German influence on Italian law began to decline and the common law tradition, associated with the victorious Anglo-Americans, rapidly gained prestige, at least with the avant-garde of the legal profession. After all, the civil law tradition with its emphasis on legislation and codification had proved impotent in preventing the rise of totalitarianism and dictatorship. The new institutional order of the free world thus had to recognize a significantly increased role of judicial power in order to effectively protect individual rights. And Italy was firmly committed to becoming part of the new free world. As a result of the agreements made between Churchill and Stalin as early as 1944, there was little doubt that Italy would end up on the Western side of what was to become the iron curtain, although formally speaking, that decision was made only with the socialist and communist defeat in the 1948 elections.

One of the lead players in the anti-Fascist resistance in Florence, Piero Calamandrei (1889-1956), had an early fascination with the common law tradition. When Calamandrei became a member of the Italian Constituent Assembly, and a famous attorney and leading civil procedurist, his predilections became widely influential. Calamandrei admired in particular the important role of practicing lawyers in the making of the common law tradition. He was convinced that the influence of the practitioners could also cure the civilian tradition of its abstractness and frequent lack of realistic perspective. Calamandrei was also an early advocate of adversary procedure, a critic of the ambiguous role of the Italian prosecutor-judge, and a supporter of reorganizing the legal profession along less bureaucratic and more policy-oriented lines.

According to a table talk recollection, as a 13-year-old boy who was assisting the resistance as a messenger, Mauro Cappelletti (1927-2004) met Calamandrei 
in the mountains around Trento in the Italian north. In due course, the teenager was to carry Calamandrei's torch, to share his passion for the common law tradition, and to become the founder of the Italian reformist tradition of comparative law. For a long time, Cappelletti was the only Italian legal scholar with a worldwide reputation. His name is linked to two major collective projects, Access to Justice (1978-9) and Integration through Law (1985). In particular, his scholarly and policy contributions to our understanding of the implications and potential of judge-made law have remained unmatched. ${ }^{2}$ When Cappelletti died in 2004, he left behind a firmly established Florentine school of comparatists.

1.1 .3

The Mainstream "Scientific" Approach in the 1950s and 196os.

The Emergence of a Comparative Law Made in Italy: from Gorla's

Contract to Sacco's Legal Formants

Oddly enough, the mainstream tradition of Italian comparative law has its birthplace, at least in a sense, in a small college town in the Eastern United States, that is, in Ithaca, New York. Ithaca was the place where, since the 195os, Rudolf B. Schlesinger, the German immigrant, was conducting the preparation of his most ambitious project, his study of the Common Core of the rules governing contract formation. This project involved several key figures in the development of Italian comparative law: the young Mauro Cappelletti; Giovanni Pugliese (1914-1995), a distinguished Roman law scholar; and, perhaps most importantly, Gino Gorla (1906-1992), later recognized as the true founding father of modern comparative law in Italy. ${ }^{3}$

In 1955, Gorla, a somewhat heretical civil law professor at the University of Rome, published his highly original comparative book on contract law, Il Contratto. In this work, he pioneered the use of the case method and of a factual approach, introducing both into an area of law hitherto largely dominated by formalistic dogmatism. ${ }^{4}$ Thus, the publication of this masterpiece shook

2 CAPPelletti (gen. ed.), Access to Justice: 1. A World Survey 2. Promising Institutions 3. Emerging Issues and Perspectives 4. The Anthropological Perspective, Leiden-Boston-Milan, 1978-9; CAPPELLETTI, SECCOMBE and WEILER (eds.), Integration through Law, Europe and American Federal Experience, Berlin-New York, 1985; CAPpelletti, Giudici Legislatori?, Milano, 1984; ID., The Judicial Process in Comparative Perspective, Oxford-New York, 1991.

3 On the Cornell Common Core Project - results of which have been published in two monumental volumes: schlesinger (ed.), Formation of Contracts. A Study in the Common Core of Legal Systems, Dobbs Ferry, New York, 1968 - see MATTEI, "The Comparative Jurisprudence of Schlesinger and Sacco: A Study in Legal Influence” in RILES (ed.), Rethinking the Masters of Comparative Law, Oxford-Portland, 2001, p. $240 \mathrm{ff}$.

4 Gorla, Il Contratto. Problemi fondamentali trattati con il metodo comparativo e casistico, Milano, 1955. 
the profession. Tullio Ascarelli called it "the first Italian wide-ranging comparative work". Gorla's Il Contratto was the result of years of searching for alternatives to the "dogmatic-conceptual" approach (as he defined it) prevailing in the Italian legal culture. Gorla had looked for such alternatives mainly in the United States. Between 1948 and 1949, he visited many American law schools and established particularly close ties with the Cornell Law School where he met Rudolf Schlesinger (1909-1996) with whom Gorla began a seminal scholarly dialogue. He found that the American case-based and inductive approach freed jurists from the intellectual strait-jacket of the broad and abstract concepts that Italian jurisprudence had borrowed from the German Allgemeine Rechtslehre. To Gorla, the American approach was like a breath of fresh air. Il Contratto was the product of this encounter with the American legal culture. Here, for the first time, not only in Italy but in all of continental Europe, key questions of contract law were addressed from an historical and comparative perspective, discussed in a case method fashion and with reference to four major legal systems - the Italian, French, English, and American.

The impact of Gino Gorla's work on comparative law was simply enormous. It opened completely new vistas for legal research. It also attracted the particular interest of Rodolfo Sacco (b.1923), a young private law scholar then teaching at the University of Trieste. Sacco was not directly involved in the Common Core project at Cornell and had never studied the common law in a systematic fashion, but he was greatly inspired by Schlesinger's approach as well as by Gorla's foundational work. Once interviewed about his own contribution to comparative law, Sacco declared with excessive modesty: "I have been a notary who put into writing, using some neologism when necessary, the new things discovered by R. David, R. Schlesinger and G. Gorla".5

Sacco's remark is certainly a serious understatement, but it remains true that the most influential version of Italian comparative law today - Sacco's theory of "legal formants" - has its roots in the post-World War II tradition founded by René David in France, Konrad Zweigert in Germany, and Gino Gorla in Italy. The hallmark of this tradition is the idea of functionalism-structuralism which is now part of the mainstream of professional Western comparative law. ${ }^{6}$

After having tested it in his teaching at Trieste as early as $195^{8-}-59$, Sacco first formulated his theory of "legal formants" under the label of "legal components" in an article exploring some aspects of the law of the Romanist

5 SAcco, Che cosè il diritto comparato?, Milano, 1992, pp. 284-85.

6 On the notion of functionalism-structuralism in comparative law, see GRAZIADEI, "The Functionalist Heritage" in LEGRAND and MUNDAY (eds.), Comparative Legal Studies: Traditions and Transitions, Cambridge, 2003, p. $100 \mathrm{ff}$. 
tradition. ${ }^{7}$ He fully developed his theory in a report for the International Academy of Comparative Law meeting in Teheran in $1974 .{ }^{8}$ It became widely known through Sacco's treatise Introduzione al diritto comparato ${ }^{9}$ and finally became available in English through a translation by James Gordley in $1991 .{ }^{10}$

As described in the leading American comparative law casebook, the methodology of legal formants looks deceptively simple:

"Professor Sacco has shown that there often is not, in a given legal system, a single unvarying rule on a particular point, but rather a series of different (sometimes conflicting) formulations of the applicable rule, depending on the kind of source consulted. The code may say one thing, the courts another; scholars may state the rule differently; the tacit rule actually followed may again be different from what anyone says it is. These different possible formulations are 'formants' (the term being borrowed from phonetics, the science that studies sounds) of the rule as it obtains in that particular jurisdiction. Understanding a legal system requires attention to the different incidences of its rules at various levels of practice and layers of discourse. An important reason for such differences may be that the 'formants' of a rule derive from different sources: for instance, the legislature's rules may derive from a particular foreign system, while scholars have systematized them using concepts and principles borrowed from another. This phenomenon is particularly noticeable in the many civil law systems which, like Italy, initially adopted codes based on the French prototype but later fell under the spell of German legal scholarship".11

Sacco's idea of "legal formants", that is, of a legal landscape consisting of components not necessarily coherent with each other, provided a theory for the demise of the paradigmatic Kelsenian idea of law as a pyramid of orders from the sovereign at the top to the subject at the bottom. From now on, the comparatist could no longer be content with such a rigid order. Instead, she needed to discover, analyze, and contrast with each other, a variety of "formants" in order to capture the complexity of a legal system and of its

7 SACco, "Définitions savantes et droit appliqué dans les pays romanistes", Revue Internationale de Droit Comparé, 1965, p. $827 \mathrm{ff}$.

8 SACCO, "Les buts et les méthodes de la comparaison du droit" in Rapports Nationaux Italiens au IX Congrès International de Droit Comparé, Téhéran 1974, Milano, 1974, p. 113 ff.

9 1980, 1st edn.

10 SACCo, "Legal Formants. A Dynamic Approach to Comparative Law", American Journal of Comparative Law, 1991, p. 1 ff, $343 \mathrm{ff}$. See also in English, SACCo and MONATERI, "Legal Formants" in Newman (ed.), The New Palgrave Dictionary of Economics and the Law, London, 1998, p. $53^{1} \mathrm{ff}$.

11 SChlesinger et al., Comparative Law. Cases, Text, Materials, 6th edn., Mineola, New York, 1998 , p. $288 \mathrm{ff}$. 
"rules". This represented a significant step forward in our understanding of the nature and life of the law. Indeed, the "legal formants" is the most influential formulation of the current structuralist methodology and it is probably the most important and lasting contribution of Italian scholarship to the discipline of comparative law, to the point of generating what can be called the "Italian Theory of Comparative Law".

In Italy, the mainstream approach to comparative law put private law at its center. Enriched by various methodological innovations, ${ }^{12}$ this has become the core around which comparative law in Italy has grown as a professional project. While Gino Gorla's later work focused on historical inquiries into the sources of law in the traditions of the common law and of the ius commune, ${ }^{13}$ and while Rodolfo Sacco broadened the field, particularly through his many disciples, the Italian mainstream continued to focus on the study of private law, which was kept rather strictly separate from comparison in other areas.

\subsection{Italian Comparative Law Develops: the 1980 and Beyond}

The original division of the Italian comparative law community into a commercial law school, a policy-making group, and a structuralist mainstream no longer exists today and may merely be used as a device to help us understand the major trends in today's highly diverse community of comparative law scholars. In current Italian comparative law scholarship, these three sub-traditions (to which we could add a fourth if we included the historical approach of the late Gino Gorla as a separate variant of the structuralist mainstream) often mix and blend into the work of individual scholars. Yet, the current comparative law landscape in Italy is also populated by a great variety of other, non-traditional, schools and approaches.

The private law bias referred is also about to be overcome. Public law is today at the very center of the discipline itself, relying on a flourishing group of scholars, many of them inspired by the work of Alessandro Pizzorusso (1931-2015), who since the 1980s strove for the unification of the two core components of the discipline. ${ }^{14}$ Nowadays public law comparatists engage themselves at the European and international level, taking up the challenges of a

The liveliness of a critical discussion in Italy on the methods of comparative law is confirmed by the kind of topics addressed in recent symposiums held by the AIDC ("New Topics and Methods in Comparative Law Research" conference to be held in Bergamo in May 2018) and by the SIRD ("Nuovi percorsi di diritto comparato - New Paths in Comparative Law", held in Milano in April 2017). Cfr., moreover, MONATERI (ed.), Methods of Comparative Law, Cheltenham, 2012.

13 GORLA, Diritto comparato e diritto comune europeo, Milano, 1981.

14 Pizzonusso, Sistemi giuridici comparati, Milano, 1995. 
multilevel protection of human rights as well as of the international legal order that is building upon a fruitful dialogue among the higher courts. ${ }^{15}$

Recent developments have also forced scholars in many legal areas beyond the traditional private law subjects to become comparatists of sorts. The significant "Americanization" of Italian law in the post-cold war era, together with the ongoing legal integration of Europe and, beyond it, the globalization of law, have been driving foreign, international, and comparative perspectives into many areas of domestic law, especially in the realm of economic regulation. As a result of these developments, areas outside private law are now experiencing what private law went through in earlier decades: a "comparativization" from the top down, so to speak, led by the emerging shape of the international legal order. In other words, comparative perspectives are injected into many, if not most, areas of erstwhile purely domestic law. ${ }^{16}$

Most significantly, moreover, Italian comparative law has made considerable progress towards an interdisciplinary approach involving other social sciences.

Beginning in the 1980s, Italian comparatists developed an interest in the "Law and Economics" movement in the United States and soon began to import its paradigms. The original hope that economics could offer a way to evaluate alternative institutional solutions in an objectively measurable way was eventually abandoned, albeit without much empirical experimentation. But economic analysis of law has also been combined with comparative analysis more generally and is now widely used for purposes of legal interpretation. More recently, it has also been discussed in a critical mode, especially for the purpose of exposing the economic fallacies underlying hegemonic patterns of dominance through law. ${ }^{17}$

Italian comparative law scholars have also explored the possibilities of cooperation with legal anthropology. In fact, Italy is one of the few places in the world where both the French and English traditions of legal anthropology have been known and discussed for quite some time. The study of legal anthropology (as well as of legal ethnology) has sought to understand unwritten and

15 See e.g., Fontanelli, martinico and Carrozza (eds.), Shaping Rule of Law Through Dialogue; International and Supranational Experiences, Groningen, 2009; MORELLI and pollicino, "Metaphors, Judicial Frames and Fundamental Rights in Cyberspaces", American Journal of Comparative Law, 2020, p. $616 \mathrm{ff}$.

16 Most recently and authoritatively, CASSESE, A World Government?, Sevilla, 2018.

17 The 2012 issue of the Annuario di diritto comparato e di studi legislativi has been devoted to the question of the quantitative measurements of the effects of legal rules. See, in particular, the critical perspective on the World Bank Doing Business Reports offered by GAMBARO, "Misurare il diritto?", ivi, p. 17 ff. 
even completely non-verbalized legal phenomena in various contexts. ${ }^{18}$ One should add that notions of legal pluralism were developed by Italian scholars as early as the 1920 (Santi Romano ${ }^{19}$ and Giacomo Venezian, ${ }^{20}$ among others) and that an archaeological method of inquiry into African law has been used by several Italians, including Rodolfo Sacco in his early work on Somalia. ${ }^{21}$

These interdisciplinary efforts aim to go to the very heart of legal phenomena and avoid the assumption that all law must be written or even spoken, let alone cast in official form. Overcoming this assumption, in turn, has improved and enriched the theory of legal formants, broadening its focus. In its original version, this approach challenged the traditional hierarchical view of legal sources, showing, for instance, that an article in the civil code competes with a court decision in producing the governing rule. But this challenge had remained within the confines of legal positivism, so to speak. Recent work in legal anthropology has elucidated other, non-positive, factors that are at work as well. Thus, "users" of law also influence legal change, for example, by making (non-professional) decisions that have an impact on how the law works, as when a victim's feeling of injustice drives him or her to bring a lawsuit or to pursue an appeal, or when a company seeks to maximize its profit by cutting (legal) corners. Today, Italian comparatists thus also consider "meta-legal formants" among the components that constitute a legal rule, such as political backgrounds, economic environments, ideas currently in vogue, and the need for social cohesion. This has enabled them to fully appreciate the context in which a legal rule arises, operates, and has an effect. Such an enriched, broader, version of the legal formants approach goes beyond officialdom and professionalism. It shows that legal formants are not independent of social, economic, and cultural factors and that dimensions of power, and especially of power disparity, play an important role in shaping the law. ${ }^{22}$

18 See SACCo, "Mute law", American Journal of Comparative Law, 1995, p. 455 ff.; CATERINA, "Dominanza e possesso (e proprietà?) in alcune società non umane", Rivista di Diritto Civile, 200o, p. 449 ff.; GRANDE, "L'apporto dell'antropologia alla conoscenza del diritto (Piccola guida alla ricerca di nuovi itinerari)", Rivista Critica di Diritto Privato, 1996, p. 467 ff.

19 Romano (1875-1947), L'ordinamento giuridico, first published 1918, Macerata, 2018.

20 Venezian (1861-1915), Opere giuridiche. 3. Scritti vari giuridici, sociali, politici, Roma, 1925 post mortem. SACCO, Le grandi linee del sistema giuridico somalo, Milano, 1985. NADER and Grande, "Current Illusions and Delusions about Conflict Management, in Africa and Elsewhere", Law and Social Inquiry, 2002, p. $579 \mathrm{ff}$. The issue is thoroughly explored by MARINI, "Comparazione e critica: the legacies of heterodoxy" in DE DONNO et al. (eds.), Persona e attività economica tra libertà e regola. Studi dedicati a Diego Corapi, Napoli, 2016, p. $127 \mathrm{ff}$. The task of comparative law to unveil forces and interests guiding the governing power is strongly advocated, inter alia, by sоммA, Introduzione al diritto comparato, Torino, 2014. 


\section{Italian Contributions to Comparative Law in Europe and Beyond}

"Contexts of reception" that import from abroad usually do not themselves contribute to the global legal landscape. For most of its modern history, Italian legal culture - particularly domestic - expressing itself in a recessive language, has been no exception.

Yet, in recent years, several Italian jurists, particularly comparativists, expressing themselves in English (and often in other foreign languages as well) have become quite well-known and influential abroad.

In 2017, three volumes on very basic topics, such as property, torts and contract in comparative law, have been edited in English by many Italian comparatists, ${ }^{23}$ and the Oxbridgian prestigious handbooks in comparative law are equally divided between German and Italian scholars.

Several Italian comparatists have led major cooperative projects on an international scale. Cappelletti's work on access to justice, that involved jurists from many countries, made a lasting contribution to the world of comparative legal scholarship. ${ }^{24}$ The "Common Core of European Private Law" Project, is twenty-five years old and has produced more than twenty volumes edited by two Italian comparatists and published internationally. ${ }^{25}$ Here, Sacco's legal formants analysis is being combined with the factual approach developed by Schlesinger at Cornell two generations ago. Involving more than 300 scholars from all EU countries and beyond, the Common core of European Private Law project has put Italian comparative law methods to work on the European level. ${ }^{26}$ Another notable project prominently involving an Italian comparatist

In this vein some scholars have reconstructed the roots of the discipline paying attention to its geo-political dimension revealing the ideological and strategical bias underlying it: see, matter, "The Cold War and Comparative Law: A Reflection on the Policy of Intellectual Discipline", American Journal of Comparative Law, 2017, p. 468 ff.; MONATERI, Geopolitica del diritto. Genesi, governo e dissoluzione dei corpi politici, Roma-Bari, 2013; Costantini, "Comparazione giuridica e geopolitica critica. Per una contro narrativa sulle tradizioni", The Cardozo Electronic Law Bulletin, 2011. On unveiling the global power dimension of the law, see moreover GRANDE, "I'm doing it for myself! The aggressive promotion of the individual self as the dark side of women's rights" in DE LAURI (ed.), The Politics of Humanitarianism. Power, Ideology and Aid, London, 2016, p. 77 ff.

23 Graziadei and smith (eds.), Comparative Property Law. Global Perspective, Cheltenham, 2017; Bussani, SEвок (eds.), Comparative Tort Law, Cheltenham, 2017; Monateri (ed.), Comparative Contract Law, Cheltenham, 2017 .

24 CAPPELLETTI, cit. supra note 2.

25 Cambridge University Press, Carolina Academic Publishing and Intersentia, edited by MATTEI and BUSSANI.

26 The Project has been recently extended to administrative law and a European research grant has been awarded to Mauro Bussani and Giacinto Della Cananea to carry out this task. 
is the "Principles and Rules of Transnational Civil Procedure". The project, a joint enterprise of UNIDROIT and the American Law Institute (ALI), was led by Michele Taruffo, a well-known Italian comparative law scholar, and Geoffrey Hazard, a prominent US-American proceduralist.

Beyond all this, there are various other international projects involving Italian jurists who are specialists in commercial, private, criminal, or international law, rather than fully-fledged comparatists. ${ }^{27}$ In particular, one of the most significant international codifications of so-called "soft law" is largely the work of an Italian scholar: the "UNIDROIT Principles of International Commercial Contracts" are the product of an international working group under the leadership of Michael Joachim Bonell, Gino Gorla's successor in Rome. The "Principles" are a hugely important contribution not only to comparative legal scholarship but also, and perhaps more importantly, to international commercial law practice.

Furthermore, Italian comparatists have been appointed to strategic positions at the European level, bringing their comparative perspective into crucial European institutions. ${ }^{28}$

Finally, a few articles written by Italians (mostly in English) are widely discussed and cited abroad. Ugo Mattei's innovative taxonomy of the world's legal systems, proposing a dynamic classification, has been the object of international debate. ${ }^{29}$ The same scholar was the first to present a combination of comparative law and economics to a wider international audience, creating a logo that is now in general use. ${ }^{30}$ Likewise, Alessandro Pizzorusso's modelization of judiciary and judicial review systems has not only been nationally, but also internationally, acknowledged. ${ }^{31}$

27 For instance, the methodology borrowed from the Cornell Project and based on questionnaires has been recently applied outside the private law domain and has led two Italian criminal procedure scholars to search for existing convergences or divergences among European criminal procedure systems: see QUATTRocolo and RUGGERI (eds.), Personal Participation in Criminal Proceedings. A Comparative Study of Participatory Safeguards and in Absentia Trials in Europe, Cham, 2019.

28 One of them for instance, Oreste Pollicino, has recently been appointed as a titular member to the board of directors of the FRA (European Union Agency for Fundamental Rights) and as a member of the FRA executive board.

29 MAtтei, "Three Patterns of Law: Taxonomy and Change in the World's Legal Systems", American Journal of Comparative Law, 1997, p. 5 ff.

30 Mattei, Comparative Law and Economics, Ann Arbor, 1997.

$31 \quad$ Pizzurosso, "I sistemi di giustizia costituzionale: dai modelli alla prassi", Quaderni Costituzionali, 1982, p. $5^{21}$ ff., and ID., "Italian and American Models of Judiciary and of Judicial Review of Legislation: A Comparison of Recent Tendencies", American Journal of Comparative Law, 199o, p. $373 \mathrm{ff}$. 
It would perhaps go too far to say that we Italians are currently experiencing something of an inversion of the traditional situation, that is, a development from a "context of reception" to a "context of production". Yet, in the last few decades, we have made fairly significant contributions to the progress of the discipline on a worldwide scale. Thus, for the first time in our modern history, we are not only importing foreign ideas but also exporting our own.

Exploring the influence of the Italian comparative law scholarship in Latin America can provide us with a good example of such a kind of diffusion.

\subsection{Italian Comparative Law in Latin America}

Perhaps the most valuable example of the current impact of the Italian comparative law scholarship in the world is the Latin-American context. Known as being traditionally neglected by mainstream comparative law, ${ }^{32}$ Latin American legal systems have become a genuine "comparativist's dream" thanks to the ongoing work of different sectors of the Italian academia. ${ }^{33}$ This phenomenon can be explained by two main reasons: the traditional interest of legal historians and Roman law scholars for the interactions between Italian and Latin American law and the grooving influence of the Italian "scientific" comparative approach in the region. Both aspects are accompanied by a substantial production of comparative literature in the Ibero-American language.

\subsubsection{The Contribution of Legal History}

While the influence of Italian law scholarship in Latin America is taken for granted in various fields of law, ${ }^{34}$ the reception of the "comparative" scholarship needs to be examined with a widely known caveat: comparative law scholars have no monopoly on the comparison..$^{35}$ Despite the scientific progress made by the Italian comparative law scholars in recent decades, it should be noted that a significant part of the contribution to the knowledge

32 Kleinheisterkamp, "Development of Comparative Law in Latin America" in Reimann and zimmermann (eds.), The Oxford Handbook of Comparative Law, Oxford, 2019, p. 253 ff. See also MARINI, "La costruzione delle tradizioni giuridiche ed il diritto latinoamericano", Rivista Critica del Diritto Privato, 2011, p. 164 ff., stressing that the process of almost complete "westernization" of Latin American law has made it an entirely collateral branch of the European model, therefore unattractive, for legal comparison.

33 Quotation refers to Rosenn, "Teaching Latin American Law", American Journal of Comparative Law, 1971, p. $692 \mathrm{ff}$.

34 One could weigh, for example, the transplantation of the general theory of the process (and of its dogma) through the work of Giuseppe Chiovenda, Francesco Carnelutti and Piero Calamandrei.

35 See, sмiтн, "Comparative legal scholarship as ordinary legal scholarship", Journal of Comparative Law, 2010, p. $331 \mathrm{ff}$. 
on comparative law has come from the work developed by legal historians, sociologists and philosophers. ${ }^{36}$ Namely, the ongoing influence of the Italian comparative academia in Latin America occurs regardless of the disciplinary "boxes" of the Italian research and university teaching system.

In this light, it is useful to recall the massive biographical work of Mario G. Losano (b. 1939) regarding the jurists' "ferrying ideas between the continents" due to their exile caused by fascism and racial laws (1938). ${ }^{37}$ As documented by Losano, the intense friendship between Calamandrei and Eduardo Couture (1904-1956), the celebrated Uruguayan civil procedural professor, drove a humanitarian and cultural mediation and assistance to give refuge to some Italian scholars that were forced to emigrate in South America because of the racial laws. Thanks to Couture's support, Enrico Tullio Liebman, Tullio Ascarelli and Renato Treves, among other jurists, found acceptance in Uruguay, Brazil and Argentina. The rest is history of modern Latin American law: Liebman "founded" the procedural school of São Paulo, Ascarelli enriched Brazilian tax and commercial law with comparative insights ${ }^{38}$ and Treves, after a brief stay in Montevideo, developed from Tucumán the premise of the modern empirical sociology of law..$^{39}$ Thus, far from being isolated or occasional episodes of models' circulation, these narratives are "useful auxiliary tools" for comparativists and local legal operators since they shed light on the general cultural context in which transfer and reception of ideas and legal norms take place.

Likewise, from the Roman law studies perspective, renewed attention should be paid to the initiatives and research carried out since the 1970s by Pierangelo Catalano (b. 1936) and lately developed by Sandro Schipani

36 See GRAZIADEI, "Comparative law, legal history and the holistic approach to legal cultures", Zeitschrift für Europäisches Privatrecht, 1999, p. 531 ff.; DUVE, "Legal traditions: A dialogue between comparative law and comparative legal history", Comparative Legal History, 2018, p. $15 \mathrm{ff}$.

37 See, for instance, "L'emigrazione dei giuristi milanesi nella Montevideo d'anteguerra", Rivista trimestrale di diritto e procedura civile, 1999, p. 219 ff.; "Calamandrei, Couture e un archivio giuridico contemporaneo a Montevideo", Gli argomenti umani. Sinistra e innovazione, 200o, p. 96 ff.; "Tra Uruguay e Italia: Couture e Calamandrei, due giuristi democratici nell'epoca delle dittature europee" in POLOTto, KEISER and DUVE (eds.), Derecho privadoy modernización: América Latina y Europa en la primera mitad del siglo XX, Frankfurt am Main, 2015, p. 275 ff. See also NITSCH, Renato Treves esule in Argentina. Sociologia, filosofia sociale, storia, Torino, 2014.

38 See, notably, Problemas de sociedades anónimas e direito comparado, São Paulo, 1945; "Diritti dell'America Latina e dottrina italiana", Rivista Trimestrale di Diritto e Procedura Civile, 1949, p. 906 ff. From a broader perspective, see also Ascarelli's work on the Brazilian culture: Sguardi sul Brasile, Milano, 1949 .

39 See dorado, "Las huellas de Renato Treves en Argentina: reflexiones desde la sociología", Sociologia del Diritto, 2018, p. $141 \mathrm{ff}$. 
(b. 1940) and his school. Their -"in time"- comparison has a twofold scope: to identify a connection, based on the Roman law tradition, between the Italian and Latin American law (an assimilation that reveals an attention to affinities, but also to de-contextualization and re-contextualization of texts, concepts, principles, institutes and norms), and to confirm the thesis of the existence of a "Latin American legal subsystem", with an own (pluralistic) identity. ${ }^{40}$ Under this Roman umbrella several scientific activities bear witness to the symmetrical influence between Italian and Latin American legal culture, whether in private or public law area. The twenty meetings of the Congreso Latinoamericano de Derecho Romano (first meeting in 1976 in Buenos Aires) and the publications and scientific training supported by the Centro di Studi Giuridici Latinoamericani of the University of Rome Tor Vergata (established in 1997 under Schipani's initiative) are glaring examples of that concurrent dialogue. ${ }^{41}$

\subsubsection{The Italian Scientific Approach in Latin America}

The reception of the Italian "scientific" approach in Latin American scholarship is linked to the work led by Mauro Cappelletti and to the diffusion of Sacco's theory of "legal formants". ${ }^{2}$

40 For an overview of such ideas see SCHIPANI, "Il modello giuridico - scientifico e legislativo - italiano in America Latina: il riconoscimento del sistema" in LANNI and SIRENA (eds.), Il modello giuridico - scientifico e legislativo - italiano fuori dell'Europa. Atti del II Congresso Nazionale della SIRD, Napoli, 2013; ID., "Il diritto romano nel Nuovo Mondo" in VISINTINI (ed.), Il diritto dei nuovi mondi, Padova, 1994, p. 64 ff.; catalano, "Sistemas jurídicos. Sistema jurídico latinoamericano y derecho romano", Revista General de Legislación y Jurisprudencia, 1982, p. 174 ff.; ID., "Sistema y Ordenamientos: el ejemplo de América Latina" in ID. (ed.), Mundus Novus. America. Sistema giuridico latinoamericano, Roma, 2005, p. 19 ff. In this tradition of studies see also, ESBORRAz, Subsistema jurídico latinoamericano, comparación y tradición romanística, Roma, 2020.

41 These activities are nourished by the synergistic effort of the Associazione di Studi Sociali Latinoamericani-ASSLA, and the Gruppo di ricerca sulla diffusione del diritto romano, both instituted in Sassari in 1972. More recently, it is important to mention the initiative of scientific exchange between Italy and Latin America launched by the colleagues of Roman and philosophy of law from the University of Naples Federico II. The exchange gave rise to the creation of a research network on issues ranging from the protection of human rights to the common Roman-based legal tradition. See MASI DORIA and CAScione (eds.), Tra Italia e Argentina: tradizione romanistica e culture dei giuristi, Napoli, 2013.

42 However, we cannot ignore the fact that Italian private law scholars open to comparison, such as Guido Alpa, Pietro Rescigno, and Pietro Perlingieri, are very well known in Latin America. In addition, personal efforts and experiences have contributed substantially to the scientific exchange in private law, serving as a channel for comparative dialogue. We are thinking, for example, about the fruitful relationship between the Peruvian Carlos 
Cappelletti's doctrinal organization display and phenomenological comparative method have vastly influenced areas of constitutional justice, theory of civil law procedure, access to justice, protection of diffuse interests, and alternative dispute resolution all over Latin America. Beyond the intense research exchange that Cappelletti promoted through his Florence projects and initiatives, the impact of his thought is due in large part to his continued involvement in academic activities in Latin America. His various visits to Mexico (four times from 1960 to 2003) have left a deep-rooted mark on constitutional justice. ${ }^{43}$ In 1981 , he presented his ideas on the universal movement for access to justice at the 11th National Congress of Procedural Law held at The National University of La Plata (Argentina). ${ }^{44}$ Cappelletti's connection and influence on Brazilian scholars have been decisive to the latter implementation of federal statutes on access to justice and class action, which have served as a model for other countries in the region. ${ }^{45}$

Furthermore, as one would expect after any profound scientific exchange, Cappelletti's inductive and factual approach has been perpetuated by a distinguished generation of local scholars such as Augusto Mario Morello (Argentina), Héctor Fix-Zamudio and Cipriano Gómez Lara (Mexico), Rubén Hernández Valle (Costa Rica), and José Carlos Barbosa Moreira and Ada Pellegrini Grinover (Brazil). It is indisputable, therefore, that thanks to Cappelletti's lesson Latin American procedural science (and comparative civil justice) has moved from a scholastic, dogmatic and formalistic method to an approach that conceives the law as a "social phenomenon", that is, a sociologicalevaluative science of practical problems.

This concern against the dogmatic method and analytical reasoning is emphasized among a group of Latin American scholars who have promoted the comparative method founded upon Sacco's observations of the elements at work in legal systems. Sacco's theorization has been used to claim a place

Fernández Sessarego and Francesco Donato Busnelli, or about the various research activities (including key works in legal translation) of the Colombian Fernando Hinestrosa.

43 See ferrer mac-gregor, "Mauro Cappelletti y el Derecho Procesal Constitucional, Comparado", Derecho \& Sociedad, 2007, p. $325 \mathrm{ff}$.

44 For more on this see BERIzONCE, "Virtualidad y proyecciones del movimiento del acceso a la justicia", Revista Derecho y Ciencias Sociales, 2012, p. $25 \mathrm{ff}$.

45 See Gonçalves de CAStro mende and pochmann DA Silva, "Acesso á justiça: uma releitura da obra de mauro cappelletti e bryant garth a partir do brasil 40 anos depois", Revista del Instituto Colombiano de Derecho Procesal, 2015, p. 47 ff.; DE Oliveira, "Mauro Cappelletti and the Brazilian Procedural Law", Revista da Faculdade de Direito, 2017, p. 381 ff.; GIDI, "Class Actions in Brazil: A Model for Civil Law Countries", American Journal of Comparative Law, 2003, p. $311 \mathrm{ff}$. 
in comparative law as an autonomous science and to better ponder the role of cultural and unwritten factors in the reception of foreign legal solutions. ${ }^{46}$

Although Sacco's scientific impact can be easily understood due to the traditional influence of Italian doctrine in Latin American private law, ${ }^{47}$ it is nonetheless worth noting that an important boost to the cultural exchange on critical comparative law comes from the in situ initiatives undertaken by contemporary comparatists linked to Sacco's school. ${ }^{48}$ In this regard, particular significance assumes a line of study developed by Lucio Pegoraro and his disciples in the domain of comparative public law. His leading research on the use of the scholarly doctrine by Latin American's high courts reveals the weight of the cultural circulation "among formants" in order to explain the domestic judge's behavior ${ }^{49}$ Moreover, Pegoraro's reflections on the methodology of Latin America's public comparative research highlight the need to break away from the Eurocentric cultural mirage or "fiction". 50 To achieve this goal, comparative scholars are called to look at the autochthonous forms of law

46 See, e.g., the extensive work on issues of civil liability and jural act of the Peruvian civil law by Professor Leysser León: ID., El sentido de la codificación civil: estudios sobre la circulación de los modelos jurídicos y su influencia en el Código civil peruano, Lima, 2004; ID., Derecho privado. Parte general. Negocios, actos y hechos jurídicos, Lima, 2019. On the employment of Sacco's premises see CAM Pos DUtRA, "Transplantes Jurídicos: história, teoria e crítica no Direito Comparado", Revista da Faculdade de Direito da UfRGS, 2018, p. 76 ff.; MíGUEZ NúÑEZ, "Comparar: conversaciones con Rodolfo Sacco", Revista Chilena de Derecho Privado, 2011, p. 193 ff.; FERRANTE, "Entre el derecho comparado y derecho extranjero. Una aproximación a la comparación jurídica", Revista Chilena de Derecho, 2016, p. 601 ff.; MORENO-CRUZ, "Herramientas para un análisis de derecho comparado" in SAUCIER CALDERón and CAmpos bernal (eds.), Viajes y fronteras de la enseñanza del derecho comparado, Lima, 2018, p. $215 \mathrm{ff}$.

47 Except for a brief article, published in a renowned Spanish journal ("Elogio a la uniformidad del Derecho, Elogio a la diversidad del Derecho", Anuario de Derecho Civil, 20o8, p. 445 ff.), SACCO's work has not been translated into Spanish. The Brazilian reader can instead consult his manual, translated in 2001 by DE FRADERA, Introdução ao direito comparado, São Paulo. In Brazil the influence of Italian scholarship and sAcco's school has not been limited to private law. See, for example, GRANDE, Imitação e direito: hipóteses sobre a circulação dos modelos, Porto Alegre, 2009.

48 All that is not only materialized through visits and stays, but also through the development of longer-term activities. Consider, for instance, Ugo Mattei's academic initiative, the International University College of Turin (IUC). From 2006 IUC promotes an interdisciplinary and comparative study of law by engaging students and young scholars with special emphasis on Latin America and the "global south".

49 See pegoraro and figueroa mejía (eds.), Profesores yjueces. Influjos de la doctrina en la jurisprudencia de los tribunales constitucionales de Iberoamérica, Ciudad de México, 2016.

50 To use Jorge Esquirol's recent expression: Ruling the Law Legitimacy and Failure in Latin American Legal Systems, Cambridge-New York, 2019. 
production and to use local parameters for their comparison. ${ }^{51}$ Remarkably, these premises have been institutionalized in the creation of the Centro di studi sull'America latina of the Bologna University (2013). The Center hosts a summer school in methodology of comparative legal research and promotes several publications on Latin American law. Current contributions from Bolognian school comparativists such as Serena Baldin, Silvia Bagni, Giorgia Pavani and Sabrina Ragone, are particularly fruitful in this field. ${ }^{52}$

The strong awareness of a non-Eurocentric conception of the Latin American legal system is a notable constant among the Italian comparativists committed to a historical and political reading of law. Losano's pioneering criticism of ethnocentrism in comparative taxonomies ${ }^{53}$ (and Mattei's dynamic classification) lead to new Italian investigations engaged in the search for the true legal identity. ${ }^{54}$ In this connection, Mattei's ${ }^{55}$ and Somma's ${ }^{56}$ critical attention to various aspects of the "Pan-Americanization" and "modernization" of Latin American law as well as Monateri's narratives about geopolitics, globalization and the making of legal hierarchies, show a natural (and unexplored) bond

51 See pegoraro, Teoría y modelos de la comparación. Ensayos de Derecho constitucional comparado, Santiago de Chile, 2016; ID., "América Latina como categoría y objeto de comparación (Coordinadas metodológicas para el estudio comparado de los sistemas jurídicos latinomaericanos", Diritto pubblico comparato ed europeo, 2018, p. 81 ff.; ID., "Ruolo della dottrina, comparazione e legal tourism", Diálogos de Saberes. Investigaciones en derecho y ciencias sociales, 2015, p. 219 ff. For an outstanding application of these premises see BALDIn, Il buen vivir nel costituzionalismo andino. Profili comparativi, Torino, 2019.

$5^{2} \quad$ See https://centri.unibo.it/csal/it/pubblicazioni.

53 Losano, I grandi sistemi giuridici. Introduzione ai diritti europei ed extraeuropei, 4th edn., Roma-Bari, 2000.

54 ROSTI, "Sobre la existencia de un sistema jurídico iberoamericano. La reconstrucción de un debate y prospectivas de investigación" in ANSUÁTEGUI ROIG et al. (eds.), El Derecho en red: estudios en homenaje al profesor Mario G. Losano, Madrid, 2006, p. 417 ff.; CASTELlUCCI, Il sistema jurídico latinoamericano. Una verifica, Torino, 2011. One aspect of particular importance is the growing interest in the study of indigenous law and unwritten formants. See, for instance, LOSANO (ed), Un giudice due leggi. Il pluralismo normativo e conflitti agrari in Sud America, Milano, 2004; MARCElli (ed.), I diritti dei popoli indigeni, Roma, 2009; MÍGUEZ NÚÑEZ, Terra di scontri: alterazioni e rivendicazioni del diritto alla terra nelle Ande centrali, Milano, 2013; LANNI, "Diritti indigeni e tassonomie del sistema in America Latina", Annuario di Diritto Comparato e di Studi Legislativi, 2013, p. 159 ff.; ID., Il diritto nell'America Latina, Napoli, 2017; Baldin, Il buen vivir nel costituzionalismo andino, cit. supra note 51.

55 "Transformaciones del mundo globalizado y derecho de propiedad durante la vigencia del Código Civil peruano: veinte años de saqueo imperialista y el potencial de resistencia de los juristas", Derecho-PUC, 2005, p. 273 ff.; "No existe Misterio del Capital alguno. El otro análisis económico del derecho. Entrevista a Ugo Mattei", THĒMIS-Revista De Derecho, 2005; "A Theory of Imperial Law: A Study on US. Hegemony and the Latin Resistance", Indiana Journal of Global Legal Studies, 2003, p. 383 ff.

56 sомма, "Le parole della modernizzazione latinoamericana. Centro, periferia, individuo e ordine" in POLOTTO, KEISER and DUVE (eds.), América Latina y Europa en la primera mitad 
with the critical legal studies that emerged in Latin America in the late twentieth century. ${ }^{57}$

Finally, we should include a note of the impact of "legal translation" in the diffusion of the Italian comparative scholarship. As in any "strong idiomatic" context, Latin America's local jurists read foreign works in their own language and as in any reception context, translation has become a fundamental piece in the circulation of ideas from overseas. The Italian comparative production is no exception: key works from Cappelletti, Pizzorusso, Losano, and Sacco translated into Latin-American languages are considered seminal readings in the region.

But while legal translation of Italian works continues to bear fruit, thanks to the increasing interest of publishers and local institutions, ${ }^{58}$ an engaging current phenomenon is destined to leave a definitive mark on both the Italian and Latin American comparative scholarship: transatlantic joint research keeps growing and as a result comparative literature in Spanish and Portuguese languages will multiply as well.

However, much still needs to be done by Latin American jurists to set a truly symmetrical relationship with their Italian peers: comparative law tools are used by a minority of them and for rather circumstantial reasons; ${ }^{59}$ there is no local production of manuals or casebooks on the subject; articles on comparative methodology are still rare or in limited circulation; the study of the discipline, moreover, has not yet spread as a separate branch in the universities. The foundations of comparative law have still to be established and the future of the discipline will depend on the ability of local scholars to internalize and spread the comparative method. Only in this way will the emerging

del siglo $x x$, Frankfurt am Main, 2015, p. 11 ff.; ID., "Il diritto latinoamericano tra svolta a sinistra e persistenza dei modelli neoliberali", Diritto pubblico comparato ed europeo, 2018, p. $57 \mathrm{ff}$.

57 On this legal movement see also GARCía and RODRÍGUEZ, Derecho y sociedad en América Latina. Un debate sobre los estudios críticos, Bogotá, 2003; WOLKMER, Introducción al pensamiento jurídico crítico, Bogotá, 2003.

$5^{8}$ In this light, special attention needs to be paid to the series Biblioteca de Derecho Comparado (Olejnik, Santiago de Chile) edited by the Peruvians Carlos Agurto gonzÁles and Sonia QUEQUEJANA MAMANI.

59 It is the case of the academic project called Principles of Latin American Contract Law, launched in 2010 with the purpose of providing a source of inspiration for the reform and modernization of contract law in Latin America. See DE LA MAZA, PIZARRO and VIDAL (eds.), Los Principios Latinoamericanos de Derecho de los Contratos, Madrid, 2017, available at https://www.boe.es/biblioteca_juridica/abrir_pdf.php?id=PUB-PR-2017-44; MOMBERG, "Harmonization of Contract Law in Latin America: Past and Present Initiatives", Uniform Law Review, 2014, p. 1 ff., available at ssRN: https://ssrn.com/abstract=2668611; VIDAL olivares and severin fuster (eds.), La Armonización del Derecho de Contratos en Latinoamerica, Santiago de Chile, $202 \mathrm{O}$. 
comparative law scholarship in Latin America be able to contribute to the current debates on cultural "adjudication", legal pluralism, unification processes, and circulation of models with a renewed and authentic voice. ${ }^{60}$

\section{Tree, Waves and Formants: the Italian Theory and the Future of Comparative Law}

\subsection{Italian Theory and the Two Main Departments of Comparative Law}

Our task now being to discuss the future of comparative law, we shall try to cope with the two main departments of the discipline: the culture/difference sector and the import/export store. Our viewpoint is that the first department serves projects of governance, whereas the second can be geared to work for critique.

The first department is, indeed, supposed to provide "the" paradigm for taxonomy within the professional community of comparative lawyers. We call the prevailing paradigm the "Family Tree theory", according to which legal cultures are more or less stable and rooted families, capable of being represented by genealogical trees. We presume that this approach has been particularly efficient in establishing a picture of the Western Legal Tradition as a whole, serving global cultural projects of governance. ${ }^{61}$

The second department by contrast focuses more on legal transplants and borrowings, which have been the major themes of the Italian Theory of Comparative Law known as the formant approach. The observation of legal transplants tends indeed to represent legal institutions more as wandering waves, which scuttle across the boundaries of different cultures. From this viewpoint legal systems are to be seen not as coherent units, but rather as "contaminations" of scattered traits. Thus, our hypothesis is that this approach, which we label as the Italian Theory, is particularly fit for critical studies, and is to be used for ideological criticism in particular.

The recurrent themes in this argument are: How is a legal family defined? How are systems grouped together? How is it that borrowings are possible? And why do they happen? How is it that the Others are represented? And who are these Others?

6o It is worth noting that substantive progress has been made on this direction by Ló PEZ MEDINA, Teoría impura del derecho. La transformación de la cultura jurídica latinoamericana, Bogotá, 2004 and ESQUIROL cit. supra note 50.

61 MATteI, "The Cold War and Comparative Law", cit. supra note 22; MONATERI, Geopolitica del diritto, cit. supra note 22 . 
Our conclusion is that the Italian Theory may now be profitably used in favor of a picture of comparative law mainly as ideological criticism: a critique of the way lawyers produce meanings as a key factor in the working of a legal culture. ${ }^{62}$

\subsection{A Radical Interpretation of Legal Transplants}

We start the argument in considering comparative law as an attempt to mediate between a "field" and an "audience", coping with the problem of selfdefinition of one culture within the legal world. It is indeed patent to us that we can speak of import/export only when we have defined where the boundary is, which means that we have stated principles of inclusion and of exclusion, of similarities and differences. ${ }^{63}$ Thus defining identities depends heavily on the framework assumed for the mapping. Of course a main subject today consists of the conscious projects of export of "Western" legal models in "exotic" areas like Latin America, with striving efforts in design of institutions, and in actual drafting of model laws, particularly in the field of Corporations. What is amazing is that such projects of governance through exports of legal patterns are carried on notwithstanding the lack of a commonly accepted theory of legal "identities" and legal transplants. From this standpoint both the "definition of identities" as well as the "import/export" can be seen as interested, non-neutral, purposive projects of governance. Now if we adopt this strategy of analysis to cope with "comparative law" as a discipline, we can see how much it has been an attempt to meet different audiences, and their expectations. Which is to say that comparative law has not normally been "transnational" at all, but rather it has grown within the frameworks of different legal traditions, responding to "inner" needs of legal elites.

What we do now, indeed, is to try to give a radical interpretation of the theory of legal transplants. If one postulates a close inherent relationship between law and the society in which it operates, legal transplants ought to be virtually impossible, and an influence of the Italian thought on Latin America would be possible only on the basis of an asserted similarity of culture and/or historical setting. But what is true is that the history of law is characterized by a prodigious amount of borrowings, rather independent from society. What is wanted in the study of the diffusion of legal ideas is not simply a catalog of borrowed

62 See MARINI, "L'Italian Style fra centro e periferia ovvero Gramsci, Gorla e la posta in gioco nel diritto privato" in CATERINI (ed.), Scritti in onore di Vito Rizzo, Napoli, 2017, Vol. I, p. $1189 \mathrm{ff}$.

63 See Kennedy, "New Approaches to Comparative Law: Comparativism and International Governance", Utah Law Review, 1997, p. 545 ff. 
"traits", but an examination of the devices for cultural sharing and selection through which legal "unity" is constructed and sustained by legal elites. ${ }^{64}$

From this standpoint the essence of a legal culture is contained in its contradictions: the picking up of foreign elements, and the ideological presentation of them as composing a unity. Legal history is dazzlingly and to a large extent a history of borrowings of legal materials from other legal systems, where social and economic factors have a much more limited and attenuated effect than it is normally supposed in theories of law and society. As Alan Watson has stated: law is largely autonomous operating in its own sphere. ${ }^{65}$

The law, in fact, is largely autonomous because it is the product of a lawmaking elite, constantly in search of a legitimation, an elite which is relatively insulated from social concerns. A kind of insulation which indeed characterized dominant academic elites during the "golden age" of Italian influence over Latin American studies.

From this point of view, the theory of legal autonomy can be used as a strong critique of the existing and governing elites of lawyers, especially in Italy and Latin America. This reading of the theory can give us a picture of the law as a battleground of competing "elites" in providing legal doctrines and rules, with strategies of societal governance which remain unconscious to the same scholars who purport them for their "scientific" merit. Since the use of a "discourse", as a technical and elaborated pattern to frame the world, is a peculiarly relevant strategy of self-legitimation, and dominance, the study of how discourses evolve and become borrowed and or transplanted, especially from Italy to Latin America, is crucial to a radical analysis of the Italian Theory based as it is on "legal formants".66

\subsection{Formants and Deconstructive Critique}

The theory of legal formants focuses on law as a social activity. A "formant" of the law is a group, a type of personnel, or a community, institutionally involved in the activity of creating law: an established legal profession, and three main types of personnel within it, as the practicing lawyer, the legal policymaker, and the legal scholar.

64 See also wiSE, "The Transplant of Legal Patterns", American Journal of Comparative Law, 1990, p. 1 ff.; GRANDE, "Legal Transplants and the Inoculation Effect. How American Criminal Procedure Has Affected Continental Europe", American Journal of Comparative Law, 2016, p. $5^{8} 3 \mathrm{ff}$.

65 WATSON, The Evolution of Law, Baltimore, 1985, p. 119.

66 DEZALAY and GARTH, The Internationalization of Palace Wars: Lawyers, Economists, and the Contest to Transform Latin American States, Chicago-London, 2002. 
These professionals produce different kinds of texts: statutes, opinions, holdings, articles, treatises, briefs, summons, broad principles, narrow rules and so on. They have an archive (authorities, precedents, etc.) and a professional, tested style to manipulate the archive. These texts and documents, and the way they are produced, the way they are interlocked, the way they are re-used by others, and so on, become a key feature in the understanding of the working of the law. To cope with these documents, the formants approach adopts a new kind of form criticism, in the widest sense, as a method to uncover, separate, and explain the various materials used to produce the texts. This approach looks for differences of all kinds between and within the documents. From this standpoint what we call the meaning of a legal text is just the link, established by professionals, between a text and another document: a plea, a scholarly article, or a decision.

The law can then be deconstructed as a set of interlocked documents used by professionals according to their personal or institutional strategies. Thus the very idea of the legal tradition is to be seen as the result of an actual strategy of considering a variety of independent documents and texts competing for hegemony as interlocked in a pattern of continuity.

The formant approach is then based on a kind of "external" study of the law as a form of sociological and economic appraisal of lawyers' activities, coupled with an "internal" analysis of documents and hegemonic influences. This approach then has two major implications. First, the legal process is seen as a competitive arena of different types of elite groups. Second, there is a total refusal of the metaphysics of the unity of the law and of the "meaning" of legal propositions.

The main idea is to substitute the model of the law as a more or less consistent system of interrelated, hierarchically connected propositions, by a model of variously interrelated "formants" within the unique setting and constraints of one legal tradition. ${ }^{67}$ The major consequence of the theory, in the field of legal interpretation and legal hermeneutics, is that a precedent, a statute, and the like, have only the meaning attached to them by competing elitarian groups, placed under different institutional constraints, and with different incentive structures.

From this point of view, the theory draws a distinction between the working rules, the practices of a legal system, and the symbolic set, the discourse used by lawyers to describe, justify, and rationalize the rules, and give a meaning to texts and authorities. The distinction is indeed one pointing at the "ideology" of a legal tradition to be understood as the system of representations located

67 See also MATteI, "Three Patterns", cit. supra note 29, p. $101 \mathrm{ff}$. 
in the everyday practices, ${ }^{68}$ and in the antagonism among "formants" in the production of meaning.

\subsection{From "Center" to "Periphery"}

The theory implies that it is always necessary to deconstruct the law to reach its working level, beyond the particular legal discourse of any one tradition. This deconstruction is necessary not only for the sake of comparison, but also for making meaningful economic analysis of the law. Deconstructive criticism is neither a luxury nor a philosophical intruder, but a necessity coming from within. From this standpoint the theory of formants is a global internal critique of the legal discourse. It is beyond the task of the theory to raise external critiques, but it certainly entails an anti-formalistic appraisal, and in the field of legal hermeneutics it disfavors the metaphysics of meaning.

Thus this theory can be labeled as a strategic decentralized approach to diffusionism: everything depends on the strategies of the borrowing systems. In our case it depends on Latin America, not Italy. It is indeed the borrowing system, which picks up what it needs, and uses what has been borrowed to cope with its own problems.

A "model" is highly prestigious if it is borrowed by many, but this depends less on the quality of the model, than on the circumstance that it meets the eventually very different expectations of the borrowers. Of course the "elites" of the context of production can try to design their own strategy of dominance, but as far as the process of borrowing is controlled by the elites of the receiving system, the formers' strategy can succeed only if it meets that of the latter. ${ }^{69}$ The best strategy for transplanting elites can thus be "ideology and propaganda", i.e. to induce the borrowing elites to believe that the offered model meets their expectations. Thus the basic strategy in transplanting is in a prestigious presentation of the model, as one that can easily cover important cases in a way appreciated in the receiving country, a kind of rhetoric that Italian lawyers have shown to master in their penetration of Latin American studies, more often than not with a strong, outdated reference to the glorious Roman Law. "Prestige", therefore, is a label to define complex inter-relations among cultures, and is certainly to be determined by the followers, according to their strategies, which can even become totally antagonistic toward the donor system.

68 See EAG ELton, Ideology: An Introduction, London-New York, 1991.

69 MEDINA, cit. supra note 6 o. 


\subsection{Comparative Law as Critique of Adjudication}

Thus at the very end what ensues is a new outline of the task of the Italian Theory of comparative law, as an insight into the "ceaseless discursive warfare"70 which is fought within legal cultures among competing groups. The formants approach of the Italian Theory surely clashes with positivism as a pattern in jurisprudence, and the sketch of the legal process we derive from it is that of several sources of the law. The "state" looks more like a permanently unstable compromise among competing legal sources, where values are not metaphysically embodied in the process, but are more to be seen as complex strategies of the opposing legal actors.

In terms of jurisprudence, the formant approach is then similar to some radical form of criticism, with two main differences. First, the formant approach is grounded on comparison as "the" tool of understanding law; and second, in the formant approach, the essential of the law is not reduced to working rules and the role of judges. Narratives and discourses are indeed as important as the practices for the purpose of social communication and social stability, and judges are but one of the factors, more apparent but often less important than others. The "difference" and "similarity" between two legal cultures is daily shaped and reshaped by the legal elites and their styles in their discursive practice. Thus the problem is how and why styles are selected and transmitted.

From this standpoint a major use of the Italian Theory in Latin America shows how the activity of lawyers is basically an "ideological" activity, their job being to produce meaning to make institutions work. However, what we call the Italian Theory is also a move away from this ideological mechanism. What a comparative lawyer can do, adopting the Theory, is to reveal the unofficial, ${ }^{71}$ and to critique those processes of meaning production as social and political realities, particular of a world of "contaminations". As a scholar she is to be interested in the details of consciousness, dismantling the various mechanisms of meaning production, and casting irony over interpretive practices.

As such comparative law can be a powerful tool for the critique of adjudication. Is this a viable future? Once somebody told us that the future is what happens to us while we are making other plans. Of course we can just bother with making plans, and the future will take care of itself.

70 See Jameson, Postmodernism, or the Cultural Logic of Late Capitalism, Durham, 1992, p. 397.

71 See LASSER, "Judicial (Self-)Portraits: Judicial Discourse in the French Legal System", Yale Law Journal, 1995, p. 1325 ff., p. 1343. 